\title{
DETEKSI DAN KUANTIFIKASI TELUR CACING ASCARIS SPp. PADA AIR LIMBAH DAN LUMPUR IPAL BOJONGSOANG BANDUNG
}

\author{
Husna Muizzati Shabrina' ${ }^{1)}$, Barti Setiani Muntalif( ${ }^{1)}$, Mayrina Firdayati1), Inat Shani \\ Fathuna $^{1)}$ \\ ${ }^{1)}$ Program Studi Teknik Lingkungan, Institut Teknologi Bandung, Bandung \\ E-mail: husnashabrina@students.itb.ac.id
}

\begin{abstract}
Abstrak
Kehadiran telur cacing parasit di lingkungan menjadi perhatian sejak badan kesehatan dunia (WHO) mempublikasikan versi baru dari Pedoman untuk Penggunaan Kembali Air Limbah, Materi Fekal, dan Greywater untuk Pertanian dan Perairan tahun 2006 yang menjadikan telur cacing parasit sebagai polutan yang perlu mendapat perhatian. Batas ekuivalen telur cacing dalam air limbah yang digunakan kembali adalah 1 telur/L sedangkan jumlah maksimum pada lumpur adalah kurang dari 1 telur/gram total solid (TS). Telur cacing parasit, khususnya Ascaris spp., menjadi ancaman dalam pemanfaatan kembali air limbah dan lumpur sebagai produk sampingan Instalasi Pengolahan Air Limbah Domestik (IPALD) karena sifatnya yang resisten menyebabkan waktu ketahanan telur cacing lebih panjang dibandingkan mikroorganisme lain. Penelitian ini bertujuan untuk mengetahui jumlah telur cacing Ascaris spp. pada air limbah dan lumpur IPALD Bojongsoang, Bandung. Sampel air limbah dan lumpur diambil dari kolam anaerobik, fakultatif, dan maturasi. Metode deteksi dan kuantifikasi menggunakan prinsip pencucian, flotasi dan sedimentasi. Hasil penelitian ini adalah ditemukan telur cacing Ascaris spp. baik bentuk fertil maupun infertil di semua sampel dengan jumlah telur fertil lebih banyak dibandingkan bentuk infertil. Pada lumpur kolam anaerobik, fakultatif, dan maturasi jumlah telur Ascaris spp. fertil berturut-turut adalah 202, 40, dan 39 telur/gram sedangkan telur Ascaris spp. infertil adalah 82, 22, dan 27 telur/gram. Pada air inlet, kolam anaerobik, fakultatif, dan maturasi jumlah telur Ascaris spp. fertil berturutturut adalah 3662, 1187, 613, dan 342 telur/liter sedangkan telur Ascaris spp. infertil adalah 1227, 333, 240, dan 280 telur/liter. Jumlah ini menunjukkan resiko tinggi pencemaran badan air dan daerah pertanian serta ancaman bagi kesehatan masyarakat di sekitar IPAL.
\end{abstract}

Kata kunci: Air Limbah, Ascaris spp., IPAL Bojongsoang, Lumpur, Telur Cacing Parasit

\begin{abstract}
Parasitic helminth eggs in environment has become a critical issue since WHO published new version of Guidelines for the Safe Use of Wastewater, Excreta, and Greywater in Agriculture and Aquaculture released in 2006 which establish criteria for the parasitic helminth egg as one of the main targeted pollutants. The equivalent limit for wastewater reuse is 1 helminth egg/liter while for sludge is 1 helminth egg/gram total solid. Soil transmitted helminths, specifically Ascaris spp., are a threat for municipal WWTP wastewater and sludge reuse because helminth eggs usually more environmentally persistent compared with other microorganisms. This study aims to enumerate Ascaris spp. eggs in wastewater and sludge of Bojongsoang WWTP Bandung. Sludge and wastewater samples were taken from anaerobic, facultative, and maturation ponds. Method for detection and enumeration use the washing, flotation, and sedimentation principal. The result is Ascaris spp. egg was detected in all samples with fertile form was more abundant than infertile one. In anaerobic, facultative, and maturation ponds the number of Ascaris spp. fertile egg are 202, 40, and 39 eggs/gram dry weight respectively, meanwhile for Ascaris spp. infertile egg are 82, 22 , and 27 eggs/gram dry weight. In wastewater samples, it was found that Ascaris spp. fertile eggs are 3662, 1187, 613, and 342 eggs/L, while Ascaris spp. infertile eggs are 1227, 333, 240, and $280 \mathrm{eggs} / \mathrm{L}$ in inlet, anaerobic, facultative, and maturation ponds samples respectively. Those amount show potential risk to water body and agriculture fields pollution and pose health threat to society.
\end{abstract}

Keywords: Ascaris spp., Bojongsoang WWTP, Parasitic Helminth Egg, Sludge, Wastewater 


\section{PENDAHULUAN}

Air limbah dihasilkan dari setiap kegiatan manusia terutama dari kegiatan domestik. Kenaikan jumlah penduduk akan disertai dengan naiknya jumlah air limbah yang dihasilkan. Limbah cair domestik yaitu limbah dari kakus (blackwater) dan limbah cuci selain kakus (greywater) mengandung materi pencemar yang bila dalam konsentrasi tinggi dilepas ke lingkungan akan mencemari badan air dan tanah serta mengganggu kesehatan perairan bahkan manusia. Untuk mengurangi resiko pencemaran, limbah cair domestik dapat diolah melalui Instalasi Pengolahan Air Limbah Domestik (IPALD). IPALD akan menghasilkan air hasil olahan yang dapat digunakan kembali untuk pertanian maupun perikanan.

Sebagian besar pengolahan air limbah melibatkan proses solid-liquid separation atau pemisahan antara padatan dengan air limbah. Istilah "lumpur" digunakan untuk menyatakan produk samping berupa padatan yang telah terpisahkan dari pengolahan air limbah. Kandungan utama lumpur IPALD adalah beragam senyawa organik dan anorganik sehingga cocok digunakan sebagai kondisioner tanah atau pupuk. Lumpur terproduksi yang telah diolah dapat dimanfaatkan sebagai pupuk organik di pertanian dan reklamasi tanah.

Terkait potensi penggunaan air limbah dan lumpur IPALD pada pertanian, terdapat resiko yaitu hadirnya mikroorganisme pencemar. Selain bakteri patogen, potensi bahaya yang terkandung dalam air limbah dan lumpur IPALD adalah kehadiran telur cacing parasit (parasitic helminth egg). Cacing parasit didefinisikan sebagai cacing yang mampu menginfeksi manusia melalui telurnya sebagai tahap paling infektif dari hidupnya. Telur cacing adalah agen infeksi dari cacing parasit (helminth) karena cacing membutuhkan inang sehingga tidak dapat hidup di lingkungan seperti dalam air limbah dan lumpur. Prevalensi ditemukannya telur cacing pada lumpur lebih tinggi dibandingkan pada air limbah karena telur akan menempel dan terkonsentrasi bersamaan dengan material partikulat dan terakumulasi dalam lumpur (Amoah et al., 2017).

Di dunia, konsentrasi telur cacing di lingkungan menjadi perhatian sejak badan kesehatan dunia (WHO) mempublikasikan pedoman untuk penggunaan lumpur untuk pertanian dan perairan. Penggunaan indikator kualitas lumpur berupa telur cacing parasit dianggap lebih relevan dibandingkan dengan indikator bakteri fekal koliform. Tingkat resistensi telur cacing parasit bahkan jauh melebihi bakteri fekal koliform karena tidak dapat diinaktivasi dengan klorin, sinar ultraviolet ataupun ozon (Jimenez, 2007b). Sayangnya, parameter telur cacing belum terdapat pada peraturan untuk penggunaan kembali air limbah dan lumpur di Indonesia. 
Telur Ascaris spp. adalah spesies paling banyak ditemukan pada air limbah dan lumpur yaitu sekitar 86,2\% dari keseluruhan telur cacing yang ditemukan (Jimenez, Maya dan Barrios, 2002). Ascaris spp. adalah nematode parasit (keluarga Ascaridiedae) dengan dua spesies paling penting yaitu Ascaris lumbricoides dan Ascaris suum. Nematoda lebih mampu bertahan dibandingkan Cestoda yang cepat tersisihkan kemungkinan akibat faktor kondisi anaerob, fenomena predator, dan tekanan osmosis (Scwartzbrod et al., 1987 dalam World Health Organization, 2004). Salah satu jenis nematoda yaitu Ascaris lumbricoides menjadi parameter paling umum sebagai indikator karena kemampuan telurnya untuk bertahan di lingkungan.

Penyakit infeksi cacing parasit Ascaris spp. atau yang disebut ascariasis pada manusia merupakan penyakit kecacingan paling umum yang terjadi di dunia. Ascariasis juga tergolong dalam penyakit tropis yang sering diabaikan (neglected tropical diseases, NTD). Ascariasis termasuk NTD utama di Indonesia karena sebagian besar penduduknya hidup di area endemic cacing parasit dengan estimasi 90 juta orang beresiko terkena ascariasis dan sekitar $11 \%$ kasus ascariasis di dunia terjadi di Indonesia (Tan et al., 2014). Menurut Departemen Kesehatan Indonesia, angka prevalensi kecacingan di Indonesia yaitu 45-65\% (Chadijah, Sumolang dan Veridiana, 2014). Penyakit akibat cacing parasit sangat efektif ditransmisikan ke manusia melalui kontak langsung dengan tanah, tanaman, atau air limbah terkontaminasi telur cacing, termasuk akibat irigasi dengan air limbah tak diolah ataupun yang diolah dengan kurang layak.

Penemuan telur cacing di lumpur lebih banyak ditemukan di negara-negara berkembang seperti Meksiko, Afrika Selatan, dan Lesotho. Konsentrasi telur cacing dapat mencapai 7 - 80 kali lebih tinggi di negara-negara berkembang (Jimenez et al., 2017). Penelitian terdahulu mengenai telur cacing parasit di lingkungan dilakukan oleh Firdayati et al. (2018) menyatakan bahwa ditemukan telur cacing dengan jumlah 1 - 119 telur/L di sampel air irigasi, tanah pertanian, dan tanaman di daerah semi urban Bandung yang terkontaminasi air limbah domestik perumahan sekitar yang dibuang ke drainase atau badan air tanpa pengolahan sama sekali. Selain itu penelitian terbaru mengemukakan bahwa terdapat $4-617$ telur cacing parasit per liter dari truk tinja yang melayani 17 area di Bandung (Muntalif et al., 2020). Penelitian ini bertujuan untuk melakukan deteksi dan kuantifikasi telur cacing Ascaris spp. pada air limbah dan lumpur IPALD dengan harapan dapat menjadi salah satu acuan bagi perumusan standar kualitas air limbah dan lumpur yang akan digunakan kembali di Indonesia. 


\section{METODE PENELITIAN}

Pada penelitian ini, sampel diambil dari IPAL Bojongsoang yang berlokasi di Kelurahan Bojongsari, Kecamatan Bojongsoang, Kabupaten Bandung. Instalasi Pengolahan Air Limbah Bojongsoang merupakan instalasi yang mengolah air limbah domestik dari Kota Bandung dan sekitarnya. Air limbah domestik yang diterima berasal dari buangan rumah tangga yaitu dari kamar mandi, dapur, dan pencucian. Beberapa air limbah berasal dari area komersil seperti hotel, rumah makan, sekolah, rumah sakit, pusat perbelanjaan, dan perkantoran, namun tidak menerima limbah industri. Peta wilayah pelayanan IPAL Bojongsoang ditunjukkan pada Gambar 1.

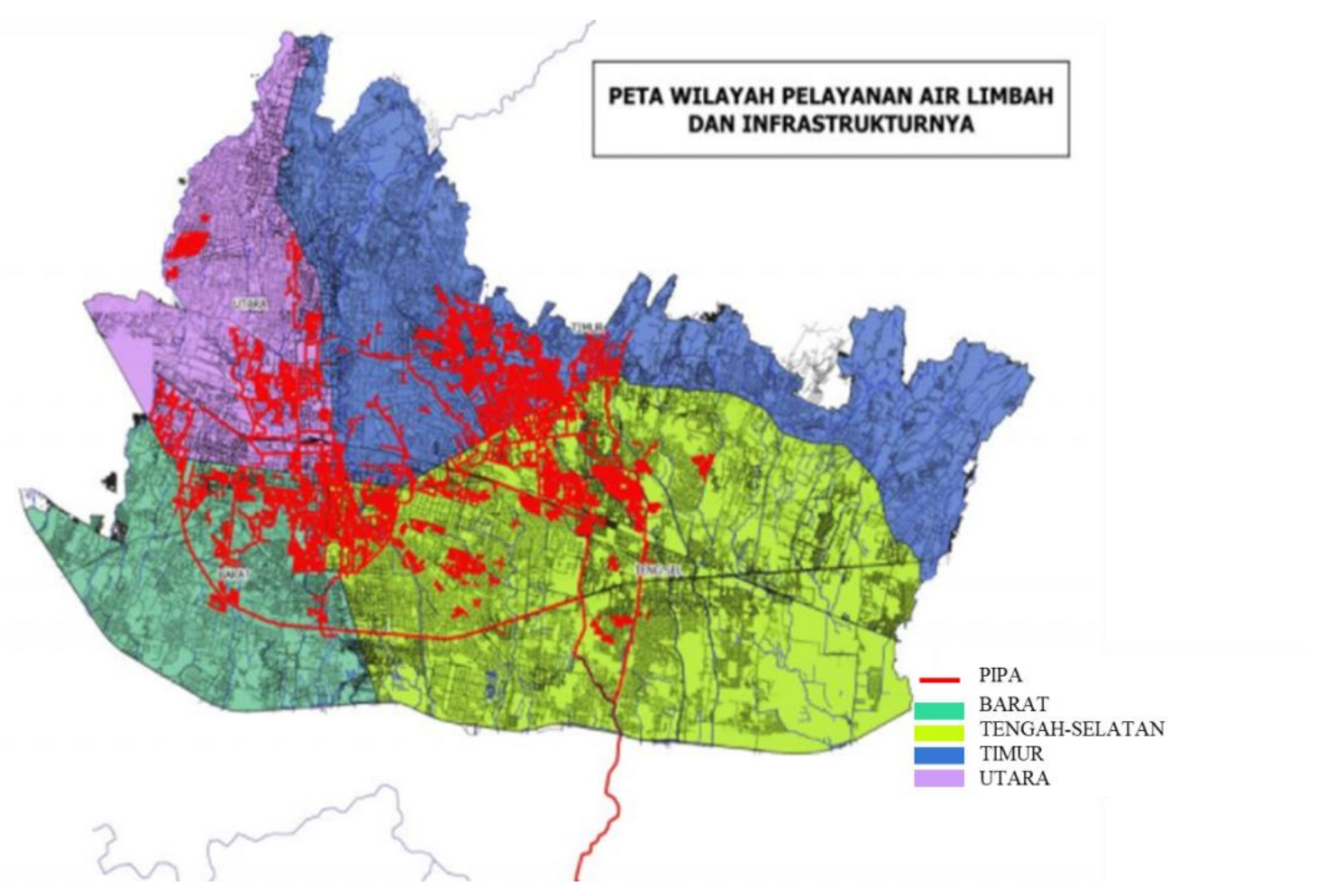

Gambar 1. Peta Wilayah Pelayanan IPAL Bojongsoang Sumber: PDAM Tirtawening, 2018

Proses pengolahan air limbah di IPAL Bojongsoang terdiri dari dua tahapan proses yaitu proses fisik dan proses biologi. Ilustrasi proses pengolahan air limbah di IPAL Bojongsoang ditunjukkan pada Gambar 2. 


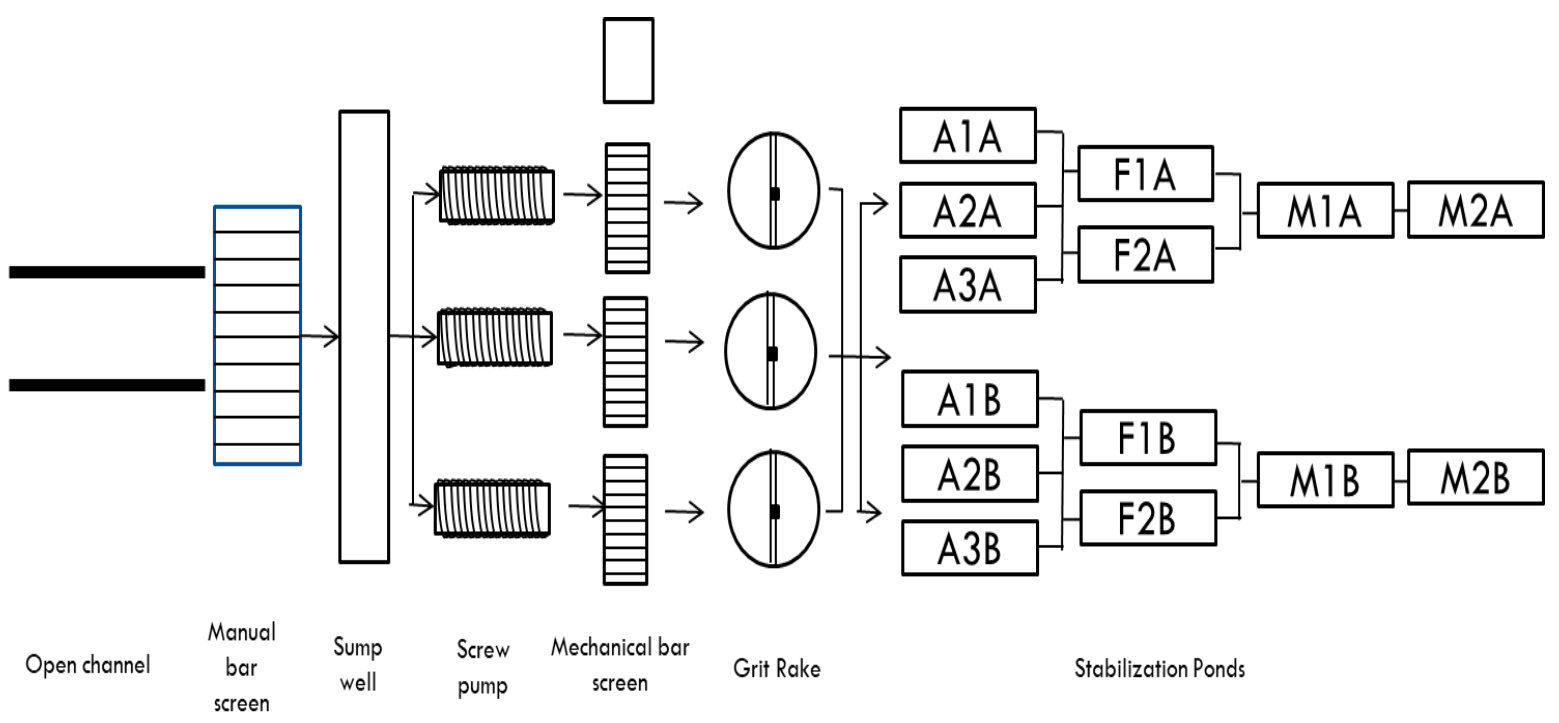

Gambar 2. Skema Proses Instalasi Pengolahan Air Limbah Bojongsoang

Sampel lumpur diambil dari kolam-kolam stabilisasi yaitu anaerobik (kode A), fakultatif (kode F), dan maturasi (kode M) sedangkan sampel air limbah diambil dari kolam-kolam stabilisasi dan inlet. Sampel diambil secara grab sampling pada rentang waktu antara pukul 8 - 11 pagi dimana debit air limbah di inlet tinggi. Sebanyak 5 liter sampel air dan 1 - 10 liter sampel lumpur basah per titik diambil dan disimpan dalam botol sampel plastik berpenutup dalam dan luar. Sampel dibawa dengan ice box dan segera dibawa ke laboratorium. Sampel diawetkan dengan menyimpan sampel pada pendingin dengan temperatur $4^{\circ} \mathrm{C}$. Pengujian sampel dilakukan di Laboratorium Kualitas Air dan Laboratorium Mikrobiologi Teknik Lingkungan ITB. Karakterisasi fisik sampel yang dilakukan beserta alat/metodenya tercantum pada Tabel 1.

Tabel 1. Parameter fisik-kimia yang diukur dan alat ukur/metodenya

\begin{tabular}{ccc}
\hline Parameter & Alat Ukur/Metode & Keterangan \\
\hline $\mathrm{pH}$ & $\mathrm{pH}$ meter & Uji di laboratorium \\
\hline Temperatur & Termometer & Uji di lapangan \\
\hline Kadar air & Metode Gravimetri & Uji di laboratorium \\
\hline
\end{tabular}

Parameter kadar air dihitung berdasarkan persamaan 1 dan parameter berat kering dihitung berdasarkan persamaan 2 .

$$
\mathrm{MC}=\frac{W_{\text {basah }}-W_{\text {kering }}}{W_{\text {basah }}} \times 100
$$


dengan :

MC = Moisture Content atau kadar air (\%)

$\mathrm{W}_{\text {basah }}=$ berat solid basah $($ gram $)$

$\mathrm{W}_{\text {kering }}=$ berat solid kering $($ gram $)$

$$
\mathrm{BK}=\mathrm{A}-\mathrm{B}
$$

dengan

$\mathrm{BK}=$ berat kering (gram)

$\mathrm{A}=$ berat cawan + sampel setelah dioven $103-105^{\circ} \mathrm{C}$ selama 1 jam

$\mathrm{B}=$ berat kosong cawan

Analisis untuk deteksi dan kuantifikasi telur Ascaris spp, dilakukan pada air limbah dan lumpur. Pada air limbah, sampel dipreparasi untuk kuantifikasi dengan menggunakan metode Bailenger termodifikasi oleh Ayres dan Mara sesuai rekomendasi WHO. Setiap sampel diendapkan selama 24 jam dalam laboratorium dengan suhu ruang. Kemudian sedimen yang terendapkan disentrifugasi pada 1200 rpm selama 15 menit. Residu kemudian dicampur dengan penyangga asam asetat $\mathrm{pH}$ 4,5 pada volume yang sama. Satu volume ekivalen eter ditambahkan hingga volume menjadi dua kali lipat lalu dikocok selama 10 menit. Sampel lalu disentrifuga selama 6 menit pada $1200 \mathrm{rpm}$. Sedimen yang dihasilkan lalu diresuspensi dengan $5 \mathrm{ml}$ larutan $\mathrm{ZnSO}_{4}$ SG 1,3 .

Pada lumpur, metode deteksi dan kuantifikasi dilakukan menggunakan metode pencucian, flotasi, dan sedimentasi berdasarkan penelitian Amoah et al., (2018). Pada prinsipnya, 20 gram sampel lumpur ditambahkan larutan deterjen Tween80 0,1\%, dihomogenisasi, lalu disaring pada ayakan 100 dan $20 \mu \mathrm{m}$. Sampel yang tertahan di ayakan $20 \mu \mathrm{m}$ dimasukkan ke dalam tabung sentrifuga dan disentrifugasi selama 10 menit pada $3000 \mathrm{rpm}$ lalu supernatan dibuang. Larutan $\mathrm{ZnSO}_{4}$ dengan specific gravity, SG 1,3 ditambahkan hingga memenuhi tabung sentrifuga, sentrifugasi kembali selama 10 menit pada $2000 \mathrm{rpm}$. Supernatan disaring kembali di ayakan $20 \mu \mathrm{m}$, residu yang tertahan dipindahkan ke dalam tabung sentrifuga. Resentrifugasi selama 10 menit pada $3000 \mathrm{rpm}$, buang supernatan, dan amati residu yang dimasukkan dalam slide McMaster di bawah mikroskop dengan perbesaran 200x. Identifikasi telur Ascaris spp. di bawah mikroskop mengacu pada ciri-ciri fisik yaitu bentuk dan ukuran telur, dicocokkan 
dengan acuan dari WHO tahun 1994. Jumlah telur cacing per gram atau per liter sampel dihitung dengan persamaan 3 .

$$
\mathrm{N}=\frac{A X}{P V}
$$

dengan

$\mathrm{N}=$ jumlah telur cacing (per gram atau per liter)

$\mathrm{A}=$ jumlah telur dalam slide atau rerata dari dua atau tiga slide

$\mathrm{X}=$ volume akhir produk $(\mathrm{ml})$

$\mathrm{P}=$ volume slide, McMaster $=0,3 \mathrm{ml}$

$\mathrm{V}=$ berat sampel awal (gram atau liter)

\section{HASIL DAN PEMBAHASAN}

Karakteristik fisik lumpur IPAL Bojongsoang yaitu $\mathrm{pH}$, temperatur, dan kadar air merupakan parameter yang mempengaruhi kelangsungan hidup Ascaris spp. Nilai pH dari sampel lumpur dan air limbah ditunjukkan pada Gambar 3.

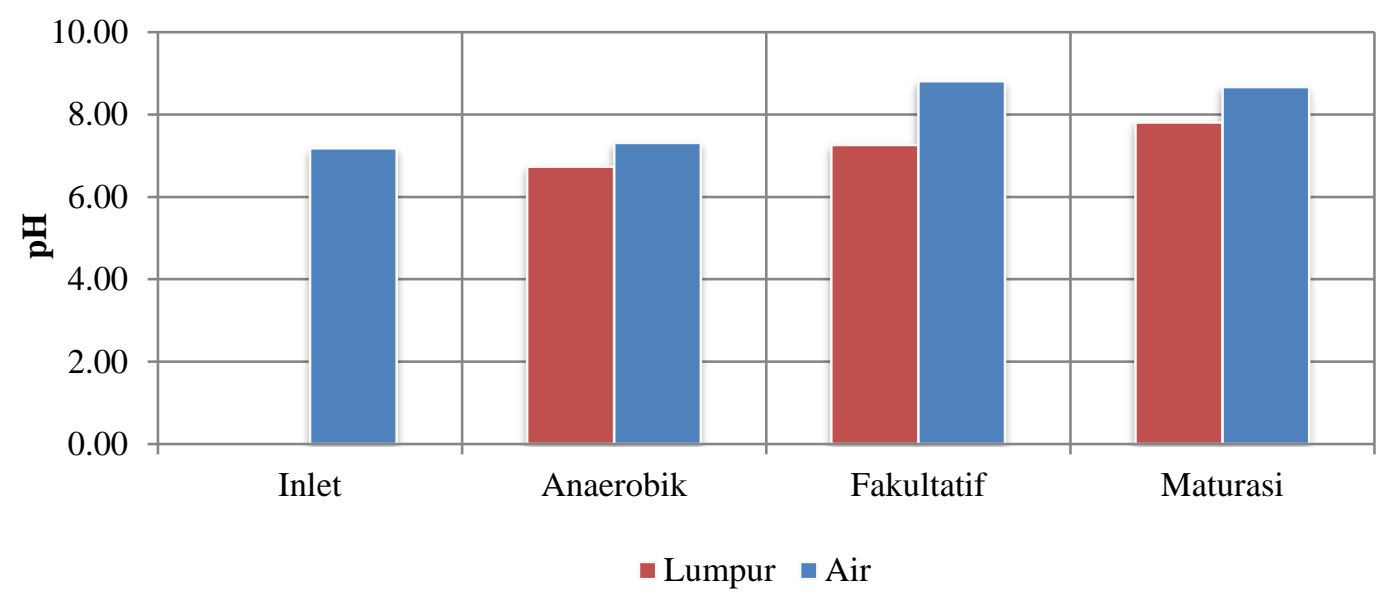

Gambar 3. pH sampel lumpur dan air limbah

pH sampel lumpur semakin meningkat dari kolam anaerobik hingga kolam maturasi. Hasil serupa ditunjukkan oleh penelitian Richard (2015) dimana pH lumpur fekal di kolam stabilisasi meningkat dari kolam anaerobik hingga maturasi, namun dengan $\mathrm{pH}$ lebih tinggi yaitu 8,45 hingga tertinggi 9,77. $\mathrm{pH}$ yang meningkat dapat terjadi akibat adanya reduksi pada proses oksidasi biologi selama lumpur berpindah pada kolam-kolam stabilisasi. Proses biologis anaerob pada kolam anaerobik menyebabkan adanya proses asetogenesis yang dapat membuat $\mathrm{pH}$ lumpur rendah. Pembentukan asam asetat dan asam propionate pada asetogenensis dapat 
membuat pembentukan hidrogen dalam jumlah besar sehingga menurunkan $\mathrm{pH}$ (Sperling and Chernicharo, 2005). Sedangkan tingginya pH pada lumpur kolam maturasi dapat diakibatkan oleh aktivitas fotosintesis yang tinggi oleh alga yang mengubah $\mathrm{CO}_{2}$ lebih cepat dibandingkan respirasi bakteri sehingga ion karbonat dan bikarbonat terdisosiasi (Mara and Pearson, 1998).

Secara keseluruhan, $\mathrm{pH}$ yang terukur di semua sampel tergolong $\mathrm{pH}$ optimum bagi telur cacing karena spesies cacing parasit yang menginfeksi manusia maupun hewan akan berhasil menghasilkan telur dan berkembang menjadi tahap infektif pada rentang $\mathrm{pH}$ 4,6 - 9,4. $\mathrm{pH}$ mempengaruhi kelangsungan hidup telur Ascaris spp. karena perbedaan ekologis signifikan dalam hal ini adalah feses dan tanah selain menyediakan $\mathrm{pH}$ optimum bagi telur juga menyediakan nutrien dan elektrolit yang diperlukan untuk perkembangan larva menuju tahap infektif (WHO, 2004)

Rerata temperatur seluruh sampel lumpur berada di rentang $26,5^{\circ} \mathrm{C}-26,6^{\circ} \mathrm{C}$. Nilai ini dicatat pada musim kemarau di bulan Januari dimana temperature ambien relatif tinggi. Nilai temperatur air, di sisi lain, bervariasi pada inlet, kolam anaerobik, kolam fakultatif, dan kolam maturasi. Temperatur sampel lumpur dan air ditunjukkan pada Gambar 4.

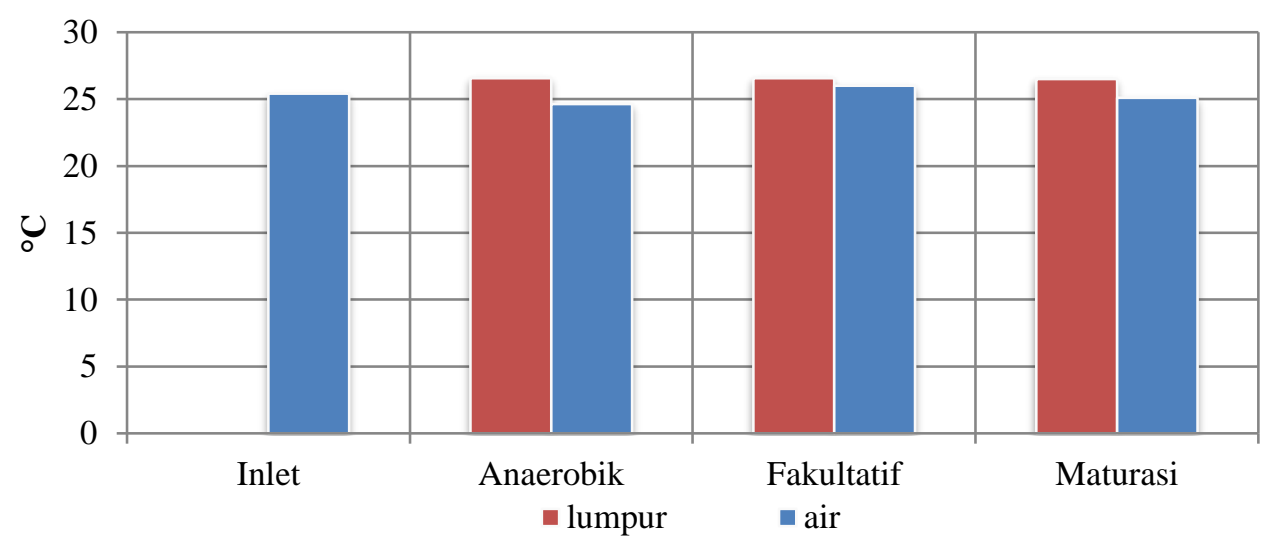

Gambar 4. Temperatur sampel lumpur dan air limbah

Temperatur merupakan salah satu faktor fisik penting bagi ketahanan telur cacing termasuk Ascaris di lingkungan. Temperatur yang sesuai bagi telur agar dapat berkembang menjadi larva infektif adalah di sekitar $25^{\circ} \mathrm{C}$ (de Silva, Chan dan Bundy, 1997). Oleh karena itu, temperatur sampel lumpur dan air limbah yang terukur merupakan temperatur yang cocok bagi perkembangan telur menjadi larva. Parameter lain yaitu kadar air lumpur ditunjukkan pada Tabel 2. 
Tabel 2. Kadar air sampel lumpur

\begin{tabular}{cc}
\hline Kolam & Kadar Air $(\boldsymbol{\%})$ \\
\hline Anaerobik & 85,16 \\
\hline Fakultatif & 85,80 \\
\hline Maturasi & 75,92 \\
\hline
\end{tabular}

Kadar air pada sampel lumpur di ketiga kolam tergolong tinggi yaitu lebih dari 70\%. Kondisi demikian terjadi karena sampel lumpur basah, diambil langsung dari kolam tanpa adanya pemadatan maupun pengeringan. Kadar air dalam lumpur akan berdampak pula pada kelembaban lumpur dimana kelembaban tinggi akan menjadikan lingkungan hidup telur Ascaris ideal. Kadar air juga akan menjadi dasar perhitungan berat kering lumpur yaitu faktor pembagi dalam perhitungan telur cacing Ascaris spp.

Karena hanya telur cacing parasit viable yang dapat menjadi infeksius, dapat dikatakan bahwa penting untuk membedakan antara telur fertil dan infertil. Telur Ascaris spp. memiliki ciri fisik yaitu berbentuk lonjong atau bulat, cangkang yang bergerigi (memiliki mamilla), lapisan luar yang tebal dan kasar, lapisan tengah yang tak berwarna dan sangat tebal, lapisan dalam yang mengandung membran inti tipis. Bentuk fertil memiliki panjang $45-75 \mu \mathrm{m}$ dan lebar $35-50$ $\mu \mathrm{m}$, sedangkan bentuk infertil secara umum lebih besar (panjang $88-94 \mu \mathrm{m}$, lebar 39-44 $\mu \mathrm{m}$ ), lebih ramping dan lebih memanjang, kandungan telur penuh dengan butiran refraktil yang bulat dan besar (WHO, 2004). Visual acuan bagi perhitungan telur Ascaris spp. di bawah mikroskop ditunjukkan pada Gambar 5.
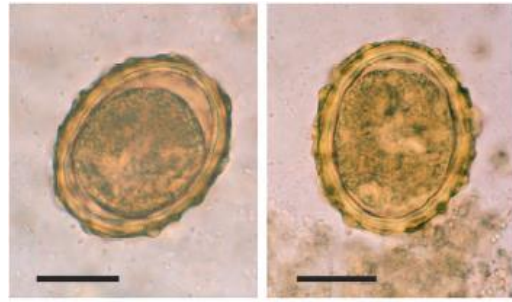

(a)

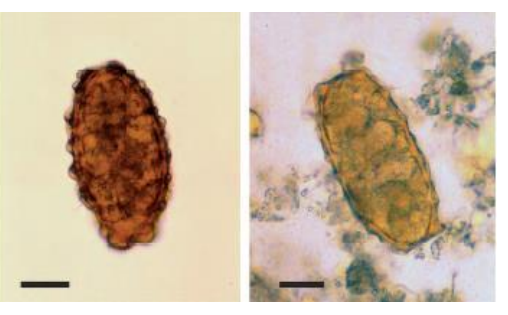

(b)

Gambar 5. Bentuk telur (a) Ascaris lumbricoides fertil (b) A. lumbricoides infertil Sumber: WHO, 1994

Hasil perhitungan telur Ascaris spp. dalam sampel lumpur ditunjukkan pada Gambar 6. Gambar 6 menunjukkan rata-rata jumlah telur Ascaris spp. fertil di pada kolam anaerobik, fakultatif, dan maturasi berturut-turut adalah 202 telur/gram, 40 telur/gram, dan 39 telur/gram. Sedangkan 
untuk Ascaris spp. infertil, jumlah telur Ascaris spp. rata-rata 82 telur/gram, 22 telur/gram, dan 27 telur/gram. jumlah telur Ascaris spp. fertil lebih banyak dibandingkan Ascaris spp. infertil di semua kolam. Jumlah telur Ascaris spp. baik fertil maupun infertil tertinggi terdapat pada kolam anaerobik kemudian menurun di kolam fakultatif sedangkan dari kolam fakultatif ke maturasi terdapat nilai yang konstan cenderung naik.

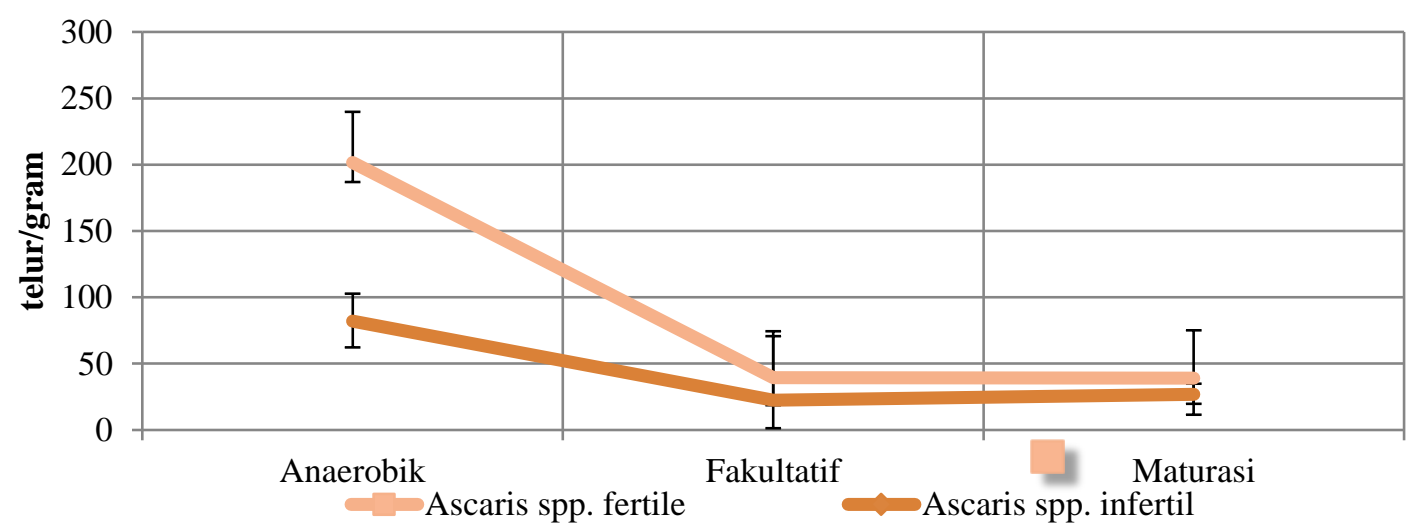

Gambar 6. Jumlah telur Ascaris spp. dalam lumpur

Kolam anaerobik menjadi tempat terjadinya sedimentasi pertama air limbah. Oleh karena itu kolam ini memiliki jumlah telur Ascaris spp. dalam lumpur paling banyak dibandingkan dua kolam lainnya. Hal ini serupa dengan hasil penelitian Bouhoum et al (2000) dimana pada kolam sedimentasi pertama ditemukan telur Ascaris spp. dalam jumlah rata-rata 6,5 telur/gram berat kering sedangkan di kolam sedimentasi kedua tidak ditemukan sama sekali. Sedangkan pada kolam fakultatif dan kolam maturasi terjadi penurunan jumlah telur Ascaris spp. karena telah tersedimentasi di kolam sebelumnya. Kolam maturasi memiliki tujuan utama menyisihkan organisme patogen sehingga kondisi lingkungan diatur agar tidak sesuai dengan kebutuhan patogen (Von Sperling, 2007).

Pedoman WHO memberikan kriteria telur cacing untuk penggunaan kembali air limbah adalah kurang dari 1 telur/L sementara dalam lumpur adalah kurang dari 1 telur/gram total solid (TS) (WHO, 2006). Sedangkan US EPA mengatur biosolid yang telah diolah digolongkan menjadi kelas A atau kelas B dengan perbedaan patogen akhir setelah pengolahan. Persyaratan lumpur agar tergolong biosolid kelas A salah satunya yaitu jumlah telur cacing 1 telur/4 gram berat kering (USEPA, 2003). Sementara di Chili baku mutu untuk air limbah untuk irigasi adalah kurang dari 1 nematode/L. Meksiko juga menerapkan batas yaitu kurang dari 5 telur/L. Meskipun penelitian oleh Bastos dkk. (2013) menyimpulkan bahwa nilai tersebut sangat ketat dan diperlukan pengkajian ulang untuk pola di negara-negara berkembang, tanpa mengabaikan 
resiko kesehatan bagi masyarakat. Oleh karena itu, bila hanya dari jumlah telur Ascaris yang ditemukan dalam sampel lumpur IPAL Bojongsoang sudah melebihi 1 telur/gram maka keseluruhan jumlah telur cacing parasit akan jauh lebih banyak dan melebihi standar WHO serta US EPA kelas A.

Efisiensi penyisihan telur cacing pada kolam stabilisasi lebih mudah diuraikan dengan parameter telur cacing dalam air limbah. Oleh karena itu, dilakukan pula perhitungan jumlah telur Ascaris spp. dalam air inlet, kolam anaerobik, fakultatif, dan maturasi. Jumlah telur Ascaris spp. dalam air saat diplot dalam grafik ditunjukkan pada Gambar 7.

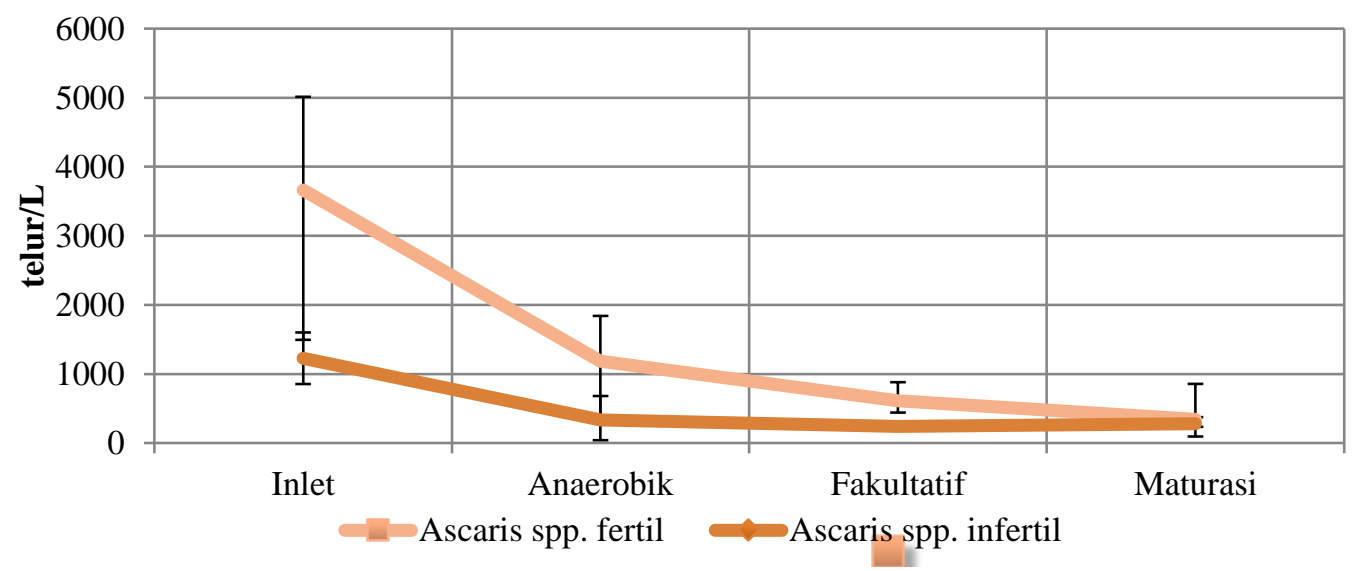

Gambar 7 Jumlah telur Ascaris spp. dalam air limbah

Serupa dengan hasil di sampel lumpur, telur Ascaris spp. fertil ditemukan lebih banyak dibandingkan dengan telur Ascaris spp. infertil. Rerata telur Ascaris spp. fertil dalam air inlet adalah 3662 telur/liter, menurun pada kolam anaerobik, fakultatif, dan maturasi berturut-turut sebesar 1187 telur/liter, 613 telur/liter, dan 342 telur/liter. Sementara jumlah telur Ascaris spp. infertil adalah 1227 telur/liter, 333 telur/liter, 240 telur/liter, dan 280 telur/liter. Proses pengolahan air limbah secara biologi secara substansial mampu mengurangi jumlah patogen dalam air limbah (US EPA, 1989). Proses ini juga mampu mengurangi jumlah patogen dengan menyediakan kondisi yang tidak sesuai untuk bertahannya patogen. Sedimentasi menjadi faktor utama untuk eliminasi patogen dalam pengolahan air limbah yang menyebabkan akumulasi patogen di sedimen (Bouhoum, et al., 2000). Pada pengolahan air limbah dalam IPALD, padatan tersuspensi tersisihkan dari air limbah selama pengolahan dari kolam stabilisasi satu ke kolam lainnya seiring dengan sedimentasi. Dengan demikian, secara umum telur cacing telah tersisihkan dari air limbah dan terakumulasi dalam lumpur (Jimenez, 2007a). 
Tingginya jumlah telur cacing parasit dalam air limbah mengindikasikan potensi banyaknya penduduk yang menderita Ascariasis dimana feses dari penderita mengandung telur cacing dan masuk ke air limbah. Sebagaimana telah diuraikan oleh Andreoli et al (2007) bahwa jumlah telur cacing parasite dalam air limbah domestik salah satunya bergantung pada tingkatan status kesehatan masyarakat sekitar dan kondisi sanitasi. Jumlah tersebut juga menunjukkan resiko tinggi pencemaran badan air dan daerah pertanian karena air dari IPAL Bojongsoang digunakan untuk irigasi masyarakat sekitar.

\section{KESIMPULAN}

Hasil pengujian terhadap sampel air limbah dan lumpur yaitu telur Ascaris spp. ditemukan di semua sampel dengan jumlah bentuk fertil lebih tinggi dibandingkan bentuk infertil. Pada lumpur kolam anaerobik, fakultatif, dan maturasi jumlah telur Ascaris spp. fertil berturut-turut adalah 202, 40, dan 39 telur/gram sedangkan telur Ascaris spp. infertil adalah 82, 22, dan 27 telur/gram. Pada air inlet, kolam anaerobik, fakultatif, dan maturasi jumlah telur Ascaris spp. fertil berturut-turut adalah 3662, 1187, 613, dan 342 telur/liter sedangkan telur Ascaris spp. infertil adalah 1227, 333, 240, dan 280 telur/liter. Dengan demikian, bila hanya dari jumlah telur Ascaris yang ditemukan dalam sampel lumpur IPAL Bojongsoang sudah melebihi 1 telur/gram maka keseluruhan jumlah telur cacing parasit akan jauh lebih banyak dan melebihi standar WHO serta US EPA kelas A.

\section{DAFTAR PUSTAKA}

Amoah, I. D., Singh, G., Stenström, T.A., and Reddy, P. (2017). Detection and Quantification of Soil-Transmitted Helminths in Environmental Samples : A Review of Current Stateof-The-Art and Future Perspectives. Acta Tropica, 169, 187-201.

Amoah, I. D., Reddy, P., Seidu, R., and Stenström, T.A. (2018). Concentration of SoilTransmitted Helminth Eggs in Sludge from South Africa and Senegal : A Probabilistic Estimation of Infection Risks Associated with Agricultural Application. Journal of Environmental Management, 206, 1020-1027.

Bastos, V. K., Cutolo, S.A., Doria, M.C.O., and Razzolini, M.T.P. (2013). Detection and Quantification of Viable Ascaris sp. and Other Helminth Eggs in Sewage Sludge. International Journal of Environmental Health Research, 23(4) : 352-362.

Bouhoum, K., Amahmid, O., and Asmama, S. (2000). Occurrence and Removal of Protozoan Cysts and Helminth Eggs in Waste Stabilization Ponds in Marrakech. Water Science and Technology, 42(10-11) : 159-164. 
Chadijah, S., Sumolang, P., and Veridiana, N. (2014). Hubungan Pengetahuan, Perilaku dan Sanitasi Lingkungan dengan Angka Kejadian Kecacingan pada Anak Sekolah Dasar di Kota Palu. Media Litbangkes, 24(1) : 50-56.

Firdayati, M., Notodarmojo, P.A., Muntalif, B.S., Trihartomo, D., Fathuna, I.S., and Somantri, K. (2018). Helminth Eggs Parameter of Water Spinach Agriculture Field in Bandung. Indonesian Journal of Urban and Environmental Technology, 2(1): 27-34.

Jimenez, B. (2007). Helminth Ova Control in Sludge: A Review. Water Science and Technology, 56 (9) : 147 - 155.

Jimenez, B. (2007). Helminth Ova Removal from Wastewater for Agriculture and Aquaculture Reuse. Water Science and Technology, 55(1-2): 485-493.

Jimenez, B., Maya, C., Barrios, J.A., and Navarro, I. (2017). Helminths and Their Role in Environmental Engineering, in Rodrigo, L. (ed.) Human Helminthiasis. London : Intech Open.

Jimenez, B., Maya, C., and Barrios, J. A. (2002). Comparison of The Quantity and Quality of the Microbiological Content of Sludge in Countries with Low and High Content of Pathogens. Water Science and Technology, 46(10) : 17-24.

Mara, D and Pearson, H. (1998). Design Manual for Waste Stabilization Ponds in Mediterranean Countries. Leeds : Lagoon Technology International Ltd.

Muntalif, B.S., Firdayati, M., Lesmono, F.D., Siregar, A.S.V., Notodarmojo, P.A., and Fathuna, I.S. (2020). Helminth Eggs Assessment of Fecal Sludge in Urban Area of Bandung, Indonesia. E3S Web of Conferences, 148, 04002.

PDAM Tirtawening. (2018). IPAL Bojongsoang. Bandung : Tirtawening PDAM Kota Bandung.

Richard, O. A. (2015). Treatment Efficiency of Waste Stabilisation Ponds for Faecal Sludge and Potential Reuse in Agriculture. Thesis, University for Development Studies.

de Silva, N., Chan, M., and Bundy, A. (1997). Morbidity and Mortality due to Ascariasis: Reestimation and Sensitivity Analysis of Global Numbers at Risk. Tropical Medicine and International Health, 2(6) : 519-528.

Von Sperling, M. (2007). Waste Stabilisation Ponds, in Biological Wastewater Treatment Series. London: IWA Publishing.

Sperling, M. von and Chernicharo, C. A. de L. (2005). Biological Wastewater Treatment in Warm Climate Regions. London: IWA Publishing.

Tan, M., Kusriastuti, R., Savioli, L., and Hotez, P.J. (2014). Indonesia: An Emerging Market 
Economy Beset by Neglected Tropical Diseases (NTDs). PLoS Neglected Tropical Diseases, 8(2) : 6-10.

US EPA. (1989). Technical Support Document for Pathogen Reduction in Sewage Sludge. Springfield: National Technical Information Service.

US EPA. (2003). Control of Pathogens and Vector Attraction in Sewage Sludge, Environmental Regulations and Technology. Washington, DC.

WHO. (1994). Bench Aids for The Diagnosis of Intestinal Parasites. France: World Health Organization.

WHO. (2004). Integrated Guide to Sanitary Parasitology. Amman, Jordan: World Health Organization.

WHO. (2006). Guidelines for the Safe Use of Wastewater, Excreta And Greywater volume 1. Geneva : World Health Organization. 